\title{
Brucella Coombs gel test: Can it replace other serological methods as a rapid test in serological diagnosis of brucellosis?
}

\section{Brucella Coombs jel testi: Brusellozun serolojik tanısında hızlı bir test olarak diğer serolojik yöntemlerin yerini alabilir mi?}

Begüm Nalça ERDiN¹ (ID), Mehmet PARLAK² (ID), Ayşe GÜVEN AYDINLI³ (ID), Feyza DEMiR² (ID)

\section{ABSTRACT}

Objective: The aim of the study was to compare the results of Brucella Coombs gel test (BCGT) with Standart tube agglutination test (STA), Coombs anti-Brucella test (CAB), Brucellacapt test (CAPT) for the serological diagnosis of brucellosis.

Methods: A total of 180 blood samples, were included in the study and were simultaneously tested with STA, CAB, CAPT and BCGT. Results of the tests were evaluated in terms of diagnostic performance and Kappa coefficient.

Results: When the tests were compared to CAB test, which is a reference method in the serological diagnosis of the brucellosis, in terms of diagnostic performance; the highest sensitivity $(98.1 \%)$ and accuracy $(98.9 \%)$ was found with BCGT. When tests were evaluated in terms of Kappa coefficient, BCGT had the highest value (0.796) and substantial agreement with CAB.

Conclusion: In conclusion, when compared with CAB, BCGT showed substantial agreement and highest sensitivity and accuracy. In addition, reduction of the period for test results and elimination of the need for experienced staff makes this test superior to other methods. Although BCGT seems to replace other tests in the serological diagnosis of brucellosis, its sensitivity and specificity should be put forward in culture-confirmed

\section{ÖZET}

Amaç: Çalıșmada brusellozun serolojik tanısında kullanılan Standart tüp aglütinasyon testi (STA), Coombs anti-Brucella testi (CAB) ve Brucellacapt testi (CAPT) ile Brucella Coombs jel testinin (BCGT) sonuçlarının karșılaștırııması amaçlanmıştır.

Yöntem: 180 kan örneği çalıșmaya dâhil edilmiş ve eş zamanlı olarak STA, CAB, CAPT ve BCGT çalıșılmıştır. Testlerin sonuçları tanısal performans ve kappa uyumu açısından değerlendirilmiştir.

Bulgular: Testler tanısal performans açısından brusellozun serolojik tanısında referans bir yöntem olan CAB testiyle karșilaștırıldığında, en yüksek duyarlılık $(\% 98,1)$ ve doğruluk $(\% 98,9)$ BCGT testinde bulunmuștur. Testler Kappa analizi ile değerlendirilip yöntemler arası uyuma bakıldığında, yine BCGT'nin en yüksek değere (0.796) ve $C A B$ ile önemli derecede uyuma sahip olduğu görülmüștür.

Sonuç: Sonuç olarak, CAB ile karșılaștırıldığında, testler arasında BCGT'nin en yüksek duyarlılık ve doğruluğu gösterdiği ve CAB ile istatistiksel olarak anlamlı ve önemli düzeyde bir uyuma sahip olduğu görülmüștür. Ayrıca, test sonuçları için sürenin kısalması ve deneyimli personele duyulan ihtiyacı ortadan kaldırılması, bu testi diğer yöntemlerden üstün kılmaktadır. Her ne kadar BCGT, brusellozun serolojik tanısında diğer testlerin yerini alabilecek gibi görünse de kültür ile doğrulanmıș vaka

${ }^{1}$ Tuzla Public Hospital, Microbiology Laboratory, İstanbul

${ }^{2}$ Van Training and Research Hospital, Microbiology Laboratory, Van

${ }^{3}$ Bursa Public Health Laboratory, Bursa

İletişim / Corresponding Author : Mehmet PARLAK

DOI ID : 10.5505/TurkHijyen.2021.83584

Erdin BN, Parlak M, Güven Aydınlı A, Demir F. Brucella Coombs gel test: Can it replace other serological methods as a rapid test in serological diagnosis of brucellosis? Turk Hij Den Biyol Derg, 2021; 78(3): 249 - 254 
cases and controls with a comprehensive study.

Key Words: Brucella, brucella coombs gel test, standart tube agglutination, coombs, brucellacapt ve kontrolleri içeren kapsamlı bir çalıșma ile BCGT'nin duyarlılığı ve özgüllüğü ortaya konmalıdır.

Anahtar Kelimeler: Brusella, brucella coombs jel testi, standart tüp aglutinasyon, coombs, brucellacapt

\section{INTRODUCTION}

Brucellosis is a zoonotic infection that causes severe morbidity and, rarely, mortality in humans. Brucella species are intracellular, aerobic, small, gram-negative coccobacilli (1). Disease is transmitted to humans who have direct contact with ill animals or with those who consume contaminated meat and milk (2). Symptoms of brucellosis are usually nonspecific, such as fever, malaise, lack of appetite, and joint and back pain, and the disease can be acute, subacute, or chronic (1,3). Each year 500,000 new Brucella cases are reported worldwide and according to the Public Health Agency of Turkey data, in 2016, the number of cases of brucellosis in our country is 514 ; morbidity rate is 6.45 in $100,000(4,5)$. Therefore, brucellosis is still hyperendemic and maintains its importance in Turkey.

Isolation of the Brucella spp. in blood and/or bone marrow culture is the gold standard for diagnosis, but isolation of the slow-growing bacterium is time consuming and requires experience, the success rate is low and laboratory-acquired infections may occur. Therefore serological tests are widely used for diagnosis. Standart tube agglutination test (STA), Coombs anti Brucella test (CAB), Brucellacapt test (CAPT) and ELISA are widely used serological tests. Rose Bengal test is often used as a screening test in brucellosis, but because of its high false-positive rate, it is not enough alone for the diagnosis (6). Although STA is a commonly used reference test, it is inadequate in the presence of blocking antibodies, and this may lead to false-negative results, especially in chronic cases and relapses $(7,8)$. In these situations CAB or CAPT should be studied for laboratory diagnosis of the disease (9). Various studies have shown that the specificity and sensitivity of $C A B$ and Brucellacapt tests are close to each other $(10,11)$. But all of these serological methods are labor-intensive, timeconsuming, and require experienced personnel to be evaluated.

A new Brucella Coombs gel test (BCGT) (Odak Brucella Coombs gel test, Toprak Medikal, Turkey), which is not affected by the blocking antibodies, was developed in Turkey. This test is performed in vials that contain gel matrix with Coombs antibodies. The test can be used both for screening and titration, and results can be given in about 2 hours (12). The test is available in Turkey and it is reported that the results are similar with CAPT and CAB (13). The aim of this study is to compare the results of the BCGT with STA, CAB, and CAPT.

\section{MATERIAL and METHOD}

\section{Study design}

A total of 180 blood samples, which were sent to the microbiology laboratory of Van Regional Research Hospital with suspicion of brucellosis from various clinics between 01.09.2014-31.12.2014, were consecutively included in the study. Of these samples, 92 (51\%) were obtained from females and 88 (49\%) from males ( $F / M: 1.05)$. The mean age of the female patients was $37.8 \pm 16.7$. The mean age of the male patients was $41.3 \pm 28.7$.

According to the instructions 180 samples, were simultaneously tested with STA, BCGT (Odak Brucella Coombs gel test, Toprak Medikal, Turkey), CAB, and CAPT (Vircell, Spain). For STA anti-B.abortus serum (S99, Refik Saydam Hifzıssıha Center, Ankara); for CAB goat anti- 
bovine whole serum (Seromed, İstanbul) was used.

Serum samples were serially diluted to $1 / 40$, $1 / 80,1 / 160,1 / 320,1 / 640$, and $1 / 1280$ titers. For the diagnosis of the brucellosis $1 / 160$ and above, titers were considered to be significant.

\section{Standard Tube Agglutination Test}

Serum samples were serially diluted to $1 / 40,1 / 80$, $1 / 160,1 / 320,1 / 640$, and $1 / 1280$ titers. Later standard anti-B.abortus serum (B.abortus S99, Refik Saydam Hifzıssiha Center, Ankara) was added to each sample and incubated at $37^{\circ} \mathrm{C}$ for 24 hours.

\section{Coombs anti Brucella test}

After STA, the tubes in which agglutination was not observed were centrifuged and washed three times with saline. The supernatant of each well was replaced with $25 \mu$ l of saline, and $25 \mu$ l of goat anti-bovine whole serum was added and incubated at $37^{\circ} \mathrm{C}$ for 24 hours.

\section{Brucellacapt test}

Test was performed in the plates according to the manufacturer's instructions and the plate was incubatedfor $18-24$ hoursat $37^{\circ} \mathrm{C}$. The wells which contain Brucella antibody negative serum samples, were found to appear as blue dot at the bottom of the plate because the antigens sink to the bottom of the well without binding the wall. Brucella antibodycontaining samples, which form a light-blue uniform appearence, have been assessed as positive.

\section{Brucella Coombs gel test}

Diluent in the amount of $100 \mu \mathrm{l}$ to the first well and $50 \mu \mathrm{l}$ to the other wells was put in the dilution plate. 5

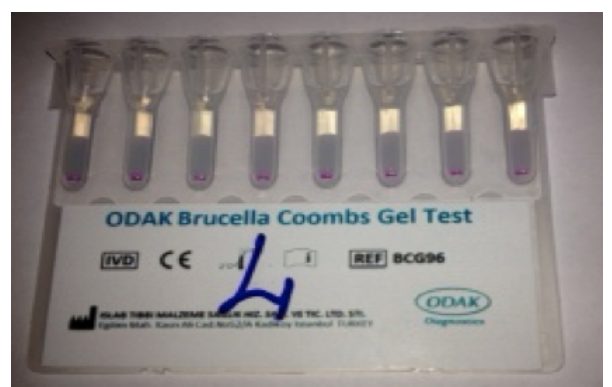

Figure 1. Brucella Coombs gel test negative $\mu \mathrm{l}$ of serum sample was added to the first well, which was then mixed. From the first well, $50 \mu \mathrm{l}$ was added to the second well. By using this method, serial dilutions were made up to $1 / 1280$, and $50 \mu \mathrm{l}$ was removed from the last well. All wells were mixed by adding $50 \mu \mathrm{l}$ of Brucella antigen suspension. After mixing the plate thoroughly, $50 \mu$ l of suspension from the corresponding well was pipetted into the corresponding well in the Brucella Gel Matrix. The Brucella Gel Matrix was centrifuged for 20 minutes and the observed results were evaluated. If the pink Brucella antigens were seen at the bottom of the tube, these wells were evaluated as negative. If the Brucella antibodies were present in the serum sample, antigen-antibody complexes were seen as pink layers on the upper part of the gel. Titrations of $1 / 160$ and above were considered positive for brucellosis (Figure 1, 2).

\section{Statistical analysis}

Although descriptive statistics are given as mean and standard deviations for continuous variables, categorical variables and descriptive statistics are given in numbers and percentages. For these categories, the Kappa coefficient was calculated to determine the concordance between the methods (14). Kappa coefficient was interpreted as follows: values $\leq$ 0 as indicating no agreement and $0.01-0.20$ as none to slight, $0.21-0.40$ as fair, 0.41- 0.60 as moderate, 0.61-0.80 as substantial, and $0.81-1.00$ as almost perfect agreement. For statistical calculations, 0.05 was accepted as significant. The Minitab (version 14) statistical software package was used for calculations.

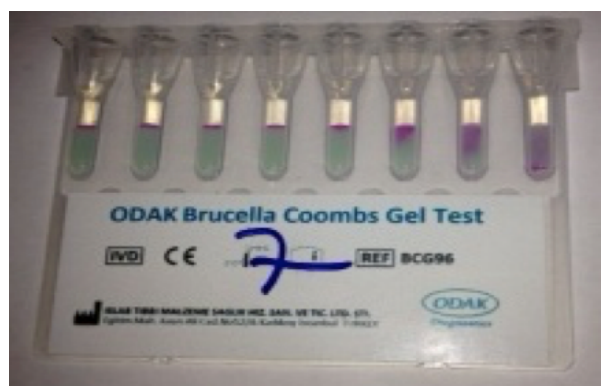

Figure 2. Brucella Coombs gel test positive with 1/640 titration (two fold dilutions were made starting from the $1 / 40$ dilution in the first well.) 


\section{RESULTS}

The number of samples above $1 / 160$ titer for STA, CAB, and CAPT were as follows respectively: 41 (22.8\%), 52 (28.9\%), and 57 (31.7\%). In BCGT, the performance of which was compared with other tests, the titration of 52 samples $(28.9 \%)$ was $1 / 160$ and above. BCGT had similar positive results with the $C A B$, which is a reference test in the diagnosis of brucellosis (Table 1).

When tests are evaluated in terms of kappa coefficient, BCGT has been found to have the highest concordance with $\mathrm{CAB}$, which is the standard method for brucellosis, (Kappa coefficient: 0,796). This is an substantial agreement and was found to be statistically significant . STA (Kappa coefficient: 0.646) and CAPT (kappa coefficient: 0.603) also has substantial agreement with CAB (Table 2).

Sensitivity, specifity, positive predictive value (PPV), negative predictive value (NPV), accuracy of STA, BCGT nad CAPT are also compared with CAB test and can be seen in detail in Table 3. The highest sensitivity (98.1\%) and accuracy (98.9\%) was found with BCGT. The highest specifity (100\%) was found with STA (Table 3).

Table 1. Comparision of BCGT, STA and CAPT results with CAB

\begin{tabular}{|c|c|c|c|c|c|c|c|c|c|}
\hline \multirow{2}{*}{\multicolumn{2}{|c|}{ Other Tests }} & \multicolumn{7}{|c|}{ CAB } & \multirow{3}{*}{$\begin{array}{r}\text { Total } \\
84\end{array}$} \\
\hline & & \multirow{2}{*}{$\begin{array}{c}\text { Negative } \\
79\end{array}$} & \multirow{2}{*}{$\frac{1 / 40}{3}$} & \multirow{2}{*}{$\frac{1 / 80}{2}$} & \multirow{2}{*}{$\frac{1 / 160}{0}$} & \multirow{2}{*}{$\frac{1 / 320}{0}$} & \multirow{2}{*}{$\frac{1 / 640}{0}$} & \multirow{2}{*}{$\frac{1 / 1280}{0}$} & \\
\hline \multirow{7}{*}{ BCGT } & Negative & & & & & & & & \\
\hline & $1 / 40$ & 3 & 16 & 4 & 0 & 0 & 0 & 0 & 23 \\
\hline & $1 / 80$ & 0 & 2 & 18 & 1 & 0 & 0 & 0 & 21 \\
\hline & $1 / 160$ & 0 & 0 & 1 & 12 & 3 & 0 & 0 & 16 \\
\hline & $1 / 320$ & 0 & 0 & 0 & 0 & 6 & 2 & 1 & 9 \\
\hline & $1 / 640$ & 0 & 0 & 0 & 0 & 2 & 5 & 3 & 10 \\
\hline & $1 / 1280$ & 0 & 0 & 0 & 0 & 0 & 0 & 17 & 17 \\
\hline \multirow{7}{*}{ STA } & Negative & 82 & 7 & 7 & 2 & 0 & 0 & 0 & 98 \\
\hline & $1 / 40$ & 0 & 14 & 7 & 2 & 0 & 0 & 2 & 25 \\
\hline & $1 / 80$ & 0 & 0 & 11 & 3 & 2 & 0 & 0 & 16 \\
\hline & $1 / 160$ & 0 & 0 & 0 & 6 & 3 & 1 & 3 & 13 \\
\hline & $1 / 320$ & 0 & 0 & 0 & 0 & 6 & 2 & 3 & 11 \\
\hline & $1 / 640$ & 0 & 0 & 0 & 0 & 0 & 4 & 1 & 5 \\
\hline & $1 / 1280$ & 0 & 0 & 0 & 0 & 0 & 0 & 12 & 12 \\
\hline \multirow{7}{*}{ CAPT } & Negative & 69 & 1 & 2 & 0 & 0 & 0 & 0 & 72 \\
\hline & $1 / 40$ & 6 & 13 & 2 & 0 & 0 & 0 & 1 & 22 \\
\hline & $1 / 80$ & 6 & 6 & 15 & 1 & 1 & 0 & 0 & 29 \\
\hline & $1 / 160$ & 1 & 1 & 5 & 5 & 2 & 0 & 2 & 16 \\
\hline & $1 / 320$ & 0 & 0 & 1 & 6 & 5 & 1 & 4 & 17 \\
\hline & $1 / 640$ & 0 & 0 & 0 & 0 & 2 & 5 & 0 & 7 \\
\hline & $1 / 1280$ & 0 & 0 & 0 & 1 & 1 & 1 & 14 & 17 \\
\hline \multicolumn{2}{|c|}{ Total } & 82 & 21 & 25 & 13 & 11 & 7 & 21 & 180 \\
\hline
\end{tabular}

CAB, Coombs anti Brucella test; BCGT, Brucella Coombs gel test; STA, Standart tube agglutination test; CAPT, Brucellacapt test 
Table 2. Kappa coefficient between tests STA, BCGT, CAPT and CAB tests

\begin{tabular}{|c|c|c|c|}
\hline Compared Tests & Kappa Coefficient \pm Std. Error & p & \%95 Confident Interval \\
\hline CAB- STA & 0.646 & 0.001 & $0.564-0.728$ \\
\hline CAB - CAPT & 0.603 & 0.001 & $0.521-0.685$ \\
\hline CAB - BCGT & 0.796 & 0.001 & $0.727-0.865$ \\
\hline
\end{tabular}

CAB, Coombs anti Brucella test; BCGT, Brucella Coombs gel test; STA, Standart tube agglutination test; CAPT, Brucellacapt test

Table 3. Sensitivity, specifity, positive predictive value (PPV), negative predictive value (NPV), accuracy of tests

\begin{tabular}{|c|c|c|c|c|c|}
\hline Compared Tests & Sensitivity & Specifity & PPV & NPV & Accuracy \\
\hline BCGT & 98.1 & 99.2 & 98.1 & 99.2 & 98.9 \\
\hline STA & 78.8 & 100 & 100 & 92.1 & 93.9 \\
\hline CAPT 1/160 & 94.2 & 93.8 & 86 & 97.6 & 93.9 \\
\hline CAPT 1/320 & 76.9 & 99.2 & 97.6 & 91.4 & 92.8 \\
\hline
\end{tabular}

CAB, Coombs anti Brucella test; BCGT, Brucella Coombs gel test; STA, Standart tube agglutination test; CAPT, Brucellacapt test

\section{DISCUSSION and CONCLUSION}

Although isolation of the bacteria is gold standard for the diagnosis of the brucellosis, because of the slow growth of Brucella spp, the low rate of isolation and special requirements for biosafety conditions, serological tests are widely used.

STA is accepted as the most commonly used standard method in the diagnosis of brucellosis all over the world. The STA test detects the total S-LPS antibodies (IgM, IgA, IgG) against the bacteria surface. However, in chronic infection or relapse, when blocking antibodies (incomplete) occur, false-negative results or low titers may be detected. To eliminate this situation, CAB or CAPT should be done $(8,9)$. However, since CAB is laborious and time consuming and CAPT is expensive, they cannot be used routinely in laboratories where large numbers of samples are analysed $(6,8)$.

BCGT is performed in wells that contain gel matrix with Coombs antibodies. In BCGT, STA and $C A B$ are performed together, and both screening and titration can be done. Furthermore, besides IgG antibodies against Brucella, IgM and IgA antibodies can be detected. With this test, the 24-48 hour period required for the test results with STA, CAPT and CAB is reduced to a very short time of about two hours. In addition, it eliminates the need for experienced staff for laboratory work and evaluation. For this reason, various studies have been carried out in different places in our country since BCGT was introduced, comparing the test with other serological methods. Irvem et al. (13) from Istanbul and Köroğlu et al. (15) from Sakarya reported that BCGT has perfect agreement with both CAB and CAPT. Turhanoğlu et al. (16) from Konya and Borsa et al. (17) from Igdir region reported that the performance of the BCGT is smilar with $C A B$. Again, Borsa and his colleagues stated that BCGT is the only rapid serological test which has similarsensitivity with CAPT.

In our study, when tests were evaluated in terms of kappa coefficient, BCGT showed the highest concordance with $\mathrm{CAB}$, which is the standard method for brucellosis, (kappa coefficient: 0,796). This is an substantial agreement according to Kappa interpretation and is statistically significant (Table 2). When the tests were compared to CAB test in terms of diagnostic performance; the highest sensitivity (98.1\%) and accuracy (98.9\%) was found with BCGT 
(Table 3). These results also support other studies conducted in our country.

As a result, compared with $C A B$, which is accepted as a reference test within three methods, BCGT has the highest diagnostic performance and highest Kappa concordance. In addition, reduction of the period for test results and elimination of the need for experienced staff makes this test superior to other methods. In the light of these data, we can propose that BCGT can replace other serological tests for the diagnosis of Brucellosis. But despite our results and all of the studies done, BCGT still needs to be evaluated with culture confirmed cases and controls in a comprehensive study.

\section{ETHICS COMITTEE APPROVAL}

* This study does not require Ethics Committee Approval.

\section{CONFLICT OF INTEREST}

The authors declare no conflict of interest.

\section{REFERENCES}

1. Young EJ. Brucella species. In: Mandell GL, Bennett $\mathrm{JE}$, Dolin R, eds. Mandell, Douglas, and Bennett's Principles and Practice of Infectious Diseases. 6th ed. Philadelphia, Pa, USA: Churchill Livingstone; 2005. pp. 2669-74.

2. Galińska EM, Zagórski J. Brucellosis in humansetiology, diagnostics, clinical forms. Ann Agric Environ Med,2013; 20(2): 233-8.

3. Aypak C, Altunsoy A, Kutta Çelik A. Epidemiological and clinical aspects of human brucellosis in eastern Anatolia. J Nippon Med Sch,2012; 79(5): 343-8.

4. Pappas G, Akritidis N, Bosilkovski M, Tsianos E. Brucellosis. N Engl J Med, 2005; 355(22): 2325-36.

5. Atay E, Metintaș S. Economic burden of brucellosis. ESTÜDAM Halk Sağlığı Dergisi 2018;3(3):71-84 .

6. Alișkan $H$. The value of culture and serological methods in the diagnosis of human brucellosis. Mikrobiyol Bul, 2008; 42(1): 185-95.

7. Sarıüuzel FM, Kayman T, Çelik I, Koç N. Comparison of standard tube agglutination, Coombs' and Brucellacapt Tests in the diagnosis of brucellosis. New J Med, 2011; 28(2): 113-5.

8. Alișkan H, Colakoğlu S, Turunç $T$, Demiroğlu $Y Z$, Yazic AC, Arslan H. Evaluation of diagnostic value of Brucellacapt test in brucellosis. Mikrobiyol Bul, 2007; 41(4): 591-5.

9. Araj GF. Update on laboratory diagnosis of human brucellosis. Int J Antimicrob Agents, 2010; 36 Suppl $1:$ S12-7.
10. Orduña A, Almaraz A, Prado A, Gutierrez MP, Garcia-Pascual A, Duenas A. Evaluation of an immunocapture-agglutination test (Brucellacapt) for serodiagnosis of human brucellosis. J Clin Microbiol, 2000; 38(11): 4000-5.

11. Gomez MC, Nieto JA, Rosa C,Geijo P, Escribano MA, Munoz A. Evaluation of seven tests for diagnosis of human brucellosis in an area where the disease is endemic. Clin Vaccine Immunol 2008; 15(6): 10313.

12. ODAK Brucella Coombs Gel Test. http://www. toprakmedikal.com

13. İrvem A, Yücel FM, Aksaray S, Bor E. Comparison of a new and rapid method, Brucella Coombs gel test with the other methods in the serological diagnosis of brucellosis. Mikrobiyol Bul, 2015; 49(2): 181-7.

14. Landis JR, Koch GG. The measurement of observer agreement for categorical data. Biometrics 1977; 33(1): 159-74.

15. Koroglu M, Aydemir AO, Demiray T, Erkorkmaz U, Ozbek A, Altindis M. Comparative evaluation of the Brucella Coombs gel test in laboratory diagnosis of human brucellosis. Biotechnol Biotechnol Equip, 2016; 30 (5): 970-5.

16. Turhanoğlu MN, Vural DG. The comparision of Brucella gel aglutination test with other Brucella tests. Dicle Tip Derg, 2015; 42(4):422-6.

17. Borsa BA, Aldag ME, Yilmaz M, Dalar ZG, Ozalp VC. Comparison of a Novel Test (ODAK Brucella Coombs Gel Test) with commonly used serological tests in human brucellosis. Clin Lab, 2016; 62(9):1671-4. 